DOI:10.17951/h.2016.50.1.459

\begin{tabular}{lcl}
\hline \multicolumn{1}{c}{ A N N A L E S } \\
UNIVERSITATIS MARIAE CURIE-SKŁODOWSKA \\
LUBLIN - POLONIA \\
VOL.L, 1 \\
SECTIO H
\end{tabular}

Poznań University of Economics and Business. Faculty of Economics

\author{
MAŁGORZATA MAGDALENA HYBKA
}

malgorzata.hybka@ue.poznan.pl

\title{
International Business Company in a Tax Haven: Selecting and Prioritizing Favourable Investment Locations
}

\author{
Przedsiębiorstwo międzynarodowe w raju podatkowym: wybór i priorytetyzacja atrakcyjnych \\ inwestycyjnie lokalizacji
}

Keywords: tax havens; MNCs; investment climate

Słowa kluczowe: raje podatkowe; przedsiębiorstwa międzynarodowe; atrakcyjność inwestycyjna

JEL Code: H20; H25; H26

\section{Introduction}

Benefits arising from application of a certain instrument of tax optimisation depend on the location of a MNC (Multinational Corporation). Different jurisdictions offer diversified tax conditions for enterprises conducting business activity at an international scale. This concerns in particular tax havens which compete for investors by including a number of tax exemptions and reliefs in their tax systems. Many of these exemptions and reliefs are available only for enterprises of a specified legal form, conducting business activity within a legally defined scope and investing in strictly specified assets.

Tax havens have always been a popular subject of discussion in economic and legal literature. Over the last few years, the so-called aggressive tax planning has been analysed more and more often. Its instruments are used by enterprises conducting economic activity in at least two jurisdictions. Aggressive tax planning means tak- 
ing advantage of technical aspects of tax systems or of differences between two or more tax systems, in order to avoid taxation. The schemes of such planning usually involve subsidiaries located in tax havens. However, what is defined as aggressive tax planning by tax authorities, may be considered tax optimization by the entrepreneurs.

A decision to locate a company (a parent company or a subsidiary) in a tax haven depends on a number of determinants of both non-tax and tax nature. The aim of this article is to present these determinants, with particular emphasis on the latter group. The priorities given to them by the multinational corporations are changing with time and are diversified depending on the companies' scope of activity, its purpose and strategy. For each type of company there is a different set of factors influencing location decisions. That is why the article also describes the categories of international business companies and the scope of their business activity. Finally, it uses the example of a holding company to discuss tax factors decisive for the location of an enterprise conducting activity at an international scale.

\section{Determinants of MNCs' location}

The choice of the location of an international enterprise is influenced by a number of factors - political, economic, legal, social and cultural. The rich relevant literature offers a number of theories concerning factors shaping the stock and structure of foreign direct investments located in particular jurisdictions. One of the most frequently discussed is the eclectic paradigm by J.H. Dunning, also known as the OLI-Model (the ownership, location and internationalization paradigm). The author of this theory indicates, as part of the new development paradigm, that there are three groups of factors influencing the location choices for foreign direct investments. These include: policy framework, economic determinants and business facilitations [Dunning, 2006, p. 206]. Taxation policy (including tax credits) is mentioned in this classification in the first group of determinants.

Such determinants as the tax burden and accounting requirements are included by economists in the category of location-specific factors, among other exogenous determinants, i.a.: political situation and cultural aspects, the size of the market, infrastructure and legal system, the development of the sector of services, the costs of starting and conducting business activity and the availability of sources of financing.

One of the key factors determining the location of an enterprise is political stability. It is measured by means of various indices. One frequently used index is BERI (Business Environment Risk Index), which takes into account political, social and economic factors in three sub-indices: the Operations Risk Index, the Political Risk Index and the R-Factor (Remittance and Repatriation Factor). The first one takes into account 15 criteria, including, among others: political stability, economic growth, attitude toward foreign investors and profits, the inflation rate and the currency convertibility. The second one enables a long-term evaluation of 
political stability and takes into account three groups of factors, including - for example - the division of the political arena, mentality, linguistic diversity, social conflicts and dependency on external forces. The last of these sub-indices informs about the solvency of a state and the possibility of transferring profits abroad. The lack of political stability discourages potential investors, as it may lead not only to a decrease in the profitability of an enterprise but even to the loss of invested capital, for example, as a result of nationalization of property or armed conflicts. However, the influence of some of the variables in this group is not that obvious. For example, a high corruption level does not always deter investors. Such countries as China, Thailand, Brazil or Mexico attract investors, despite their poor results in Transparency International's Corruption Perception Index. This phenomenon may have various reasons. For a number of investors, this factor may play a smaller role, in comparison to other determinants [Egger, Winner, 2006, p. 479-480]. Apart from that, corruption in a country may exercise different influence on investments, depending on their type [Hakkala, Norbäck, Svaleryd, 2008, p. 639; Brouthers, Gao, McNicol, 2008, p. 678].

Table 1. Factors affecting location decisions of companies according to EY's 2014 European attractiveness survey

\begin{tabular}{|l|c|c|c|}
\hline \multirow{2}{*}{\multicolumn{1}{|c|}{ Factors }} & \multicolumn{2}{c|}{$\begin{array}{c}\text { Place in rankings conducted } \\
\text { in the years: }\end{array}$} \\
\cline { 2 - 4 } & 2011 & 2012 & 2014 \\
\hline Stability and transparency of political, legal and regulatory environment & 1 & 2 & 3 \\
\hline The country or region's domestic market & 2 & 1 & 8 \\
\hline Potential productivity increase for the company & 3 & 5 & 4 \\
\hline Labor costs & 4 & 3 & 7 \\
\hline Local labor skill level & 6 & 6 & 6 \\
\hline Flexibility of labor legislation & 10 & 9 & 10 \\
\hline Transport and logistics infrastructure & 5 & 4 & 1 \\
\hline Telecommunications infrastructure & 9 & 10 & 2 \\
\hline Stability of social climate & 7 & 7 & 5 \\
\hline Corporate taxation & 8 & 8 & 9 \\
\hline
\end{tabular}

Source: [EY's Attractiveness Survey..., 2014, p. 13].

The size of the market is one of the least controversial determinants of foreign direct investments. Numerous studies confirm its positive influence on the volume of these investments. This determinant is usually measured by means of the relation of the GDP to the number of citizens and plays a particularly important role in the case of market-seeking investments. Market-seeking investors are interested in the locations which enable them to take advantage of the economics of scale, i.e. markets with a significant number of suppliers and buyers. The situation is different in the case of resource-seeking investors who make their decision about locating an enterprise dependent on such variables as availability and prices of resources, costs of labour, market of services and infrastructure [Zvirgzde, Schiller, Diez, 2013, p. 7]. 
Infrastructure is one of the most important elements of the country's investment climate (table 1). Investors take into account not only transport, telecommunication, IT or energy infrastructure, but also the legal system in a country, as well as the availability of professional services (e.g. consulting, accounting or auditing). For example, the analyses conducted by S. Globerman and D. Shapiro show that countries in which the legal order is similar to the legal order in Anglo-Saxon countries (common law) are perceived by investors as more attractive locations than other countries [Globerman, Shapiro, 2003, p. 36]. Some countries introduce legal regulations which discourage investors, as they limit the freedom of conducting business activity by enterprises. For example, establishing a holding company on Madeira (sociedade holding), as much as it offers many tax benefits, also involves a number of restrictions. Such company may not purchase its own shares, bonds of other entities (with exceptions), offer loans (except to its own subsidiaries) and conduct other activities than the ones involving purchasing shares and stocks of other companies. Some countries (including Cyprus, Barbados, Singapore) do not allow to issue bearer shares, which are instruments used relatively often by enterprises as a means of ensuring investors' anonymity.

The choice of enterprise location is also influenced by such factors as the costs of incorporation and conducting business activity. These costs include, in particular, registration, material, logistics, financial and labour costs. The significance of particular categories of costs depends on the nature of the activity of an enterprise. In the times of globalisation, the availability of financing sources loses its importance. A more significant role is played by legal regulations which limit the possibility to finance a company with debt. They include regulations concerning thin capitalisation with limitations on treating interests on loans and credits as deductible expenses.

The role of taxation in choosing the location of foreign direct investments is relatively frequently discussed by economists. The review of literature devoted to the impact of tax policy on investment decisions of economic entities is offered by such authors as J. Morisset and N. Pirnia. In their opinion, this impact depends directly on the characteristics of the investing international enterprise [Morisset, Pirnia, 2000, p. 10]. For example, it is more significant in the case of export-oriented enterprises, SMEs and those conducting activity on multiple markets.

\section{Definition and categories of International Business Company}

International Business Company (IBC) is a popular tax planning instrument. Its concept originated from the International Business Companies Act of 1984 implemented in the British Virgin Islands and has since been developed by many jurisdictions across the world, i.a. Barbados, Cyprus, Seychelles, Belize, Panama, Dubai and Nevis. Under pressure of the OECD, certain provisions of this Act were modified. For example, the amended regulations that came into force from the beginning of 
January 2005 did not include the former distinction between a company conducting business in the domestic market and a business operating only on an international scale. A new unified type was introduced - BVI Company.

International Business Company is defined as an offshore entity established under the laws of a jurisdiction, usually an offshore financial center, as a tax-exempt company which is not permitted to engage in business within the jurisdiction of its incorporation. It is mainly created both for asset protection and tax optimization purposes. Depending on the country of operation, there are diversified legal requirements and tax preferences with reference to an IBC. For example BVI Company is exempt from corporate income tax and capital gains tax. In addition, there are no sales or value added taxes imposed on its operations and no withholding tax on interest, dividends or royalties paid out by the company [Hadnum, 2009, p. 36-37]. The payroll tax from $2-14 \%$ depending on the company's size is imposed on the employees' remuneration paid by the company. The company is also exempt from stamp duty except the duty on instruments that relates to the transfer of an interest in land in the BVI or the transfer of securities of a land owning company.

Taking into account the purpose of incorporation and the scope of activities the authors describe the following types of IBC: international trading company, professional service company, offshore employment company, offshore royalty and patent company, offshore investment company, offshore property company or holding company.

International trading company acts as an intermediary between manufacturer or wholesaler and customer. It usually buys goods from related companies or third parties and sells them to foreign subsidiaries. It may be applied for re-invoicing strategy and enables profit shifting to low-tax jurisdiction. It can sell products at reasonably high prices and still adhere to the arm's length principle by for instance signing exclusive buying arrangements [International Master Tax Guide, 2009, p. 21].

Professionals providing services may use an offshore company to accumulate profits in the jurisdictions offering preferential tax treatment and protect themselves from potential claims of a third party. For this purpose they may set up a professional service company that renders services as an independent contractor in its own name and on its own account. Professionals can then claim salary from this company. Likewise, artists and sportsmen can perform their activities through such companies [Broe, 2008, p. 52].

Tax planning may also be one of the primary purposes while forming an offshore employment company. Similarly to a professional service company, it can contract to supply the services of the individuals outside the country in which they are normally resident and obtain profit free from taxation. It can employ individuals or a group of individuals working overseas. Apart from tax advantages, it is created to reduce currency exchange problems.

Offshore royalty and patent company is usually formed to purchase intellectual property (technical knowledge, patents, trademarks, copyrights, computer software) 
and to sub-license it to other interested parties. It can enter into agreements with licensees around the world who may manufacture or otherwise apply intellectual property. Offshore royalty and patent company receives franchise fees and royalties and may accumulate the profit in law-tax jurisdiction.

Offshore investment company is set up to conduct investment activities on international scale. It may benefit from reduced tax burden and in addition be used for asset protection, investment diversification and confidentiality purposes. Especially offshore property companies are applied to avoid capital gains taxes. In addition, they may be vehicles of inheritance tax planning in such countries as the United Kingdom. Individuals not domiciled in the UK who own UK property via an offshore company are not liable to inheritance tax on that property until April 2017.

The main purpose of a holding company lies in holding a long-term interest in one (or more) legally independent enterprise(s) [Eicke, 2009, p. 37]. Its exact definition depends on a country of incorporation. A holding company may be applied for tax planning purposes due to multiple tax benefits offered by certain tax havens. Other reasons for the formation of a holding company may include [Russo, 2007, p. 85]: desire for company consolidation, creation for a platform for future business acquisitions, improvement of risk management and financial flexibility.

\section{Tax determinants of company location on the example of a holding company}

Activities of any holding company structure include holding of investment (shareholding and participation in a group of companies) granting of loans, treasury and cash management (i.a. cash pooling/netting and centralizing group-wide currency risks), ownership and exploitation of intangibles, insurance, factoring, leasing, and re-invoicing [Russo, 2007, p. 86]. The primary tax considerations for determining appropriate holding location should therefore take into account all these activities.

The most significant tax determinant taken into account by entrepreneurs, regardless of the nature of the business activity they conduct, is the effective corporate income tax rate. A number of tax havens, including the Bahamas, Bermuda, the Cayman Islands, Guernsey or the Isle of Man do not impose this tax on enterprises. In European countries, the effective corporate income tax rate is relatively low in Bulgaria, Ireland, Cyprus, Latvia and Lithuania [Spengel et al., 2014, p. 7-10].

The largest tax consultancy companies draw analyses comparing tax regimes for holding companies every year. The most important tax aspects taken into account in these analyses are regulations concerning the taxation of dividends received by a company and taxation of gains on alienation of shares. In some countries, holding companies which have met special legally specified requirements, are exempt from capital gains tax (participation exemption). These conditions are relatively the most attractive for companies in such European jurisdictions as the Netherlands, Luxemburg and Malta. 
The Dutch participation exemption regime used to make the Netherlands very special among the holding locations [Eicke, 2009, p. 192]. Although other jurisdictions introduced similar provisions, this country is still high in the rankings for the best holding company regimes. In the Netherlands, dividends and gains realized on the alienation of a participation are fully exempt from taxation when the following conditions are met:

- the holding company or related party holds a participation of at least $5 \%$ of the nominal paid-up share capital of a company,

- the holding structure (holding company or its subsidiary) passes the so-called motive test or the asset test or the subject-to-tax test.

The first is considered as passed when the holding company's objective with respect to its participation is to obtain a return that is higher than a return that may be expected from regular asset management. In the second test, the subsidiary assets are analyzed in order to define their character. If over $50 \%$ of the subsidiary's asset base is made up of passive portfolio investments/assets, the subsidiary is considered an investment company and the asset test is passed. The third test takes into account the standard tax rate and is passed when the subsidiary's profit is subject to a corporate tax regime comparable to the Dutch regime which has a tax rate on profits of at least $10 \%$.

With respect to the specific character of business activity, an important determinant for the location of a holding company is the withholding tax levied on dividend payments made by a holding company as well as on the interests on debt instruments and charges for licenses and patents paid by a holding company. Some jurisdictions apply an exemption from taxation. With respect to dividends, exemption is offered to enterprises, for example, in Mauritius, Cyprus, Malta, Singapore and Hong Kong. In the case of interests on debt instruments and payments for licenses and patents, exemption is used, for example, in the Netherlands.

Usually, particular entities making up a holding are located in different jurisdictions. Therefore, in order to optimize tax obligations of a holding structure, the provisions of double taxation agreements have to be taken into account. From this perspective, European countries have an advantage over classical tax havens (such as the Bermuda Islands, the Seychelles, the Cayman Islands), which, as a rule, do not make such agreements. For example, as of January 1, 2015, Great Britain had 121 such agreements, the Netherlands - 93, Belgium - 92, Luxemburg - 74 .

What discourages investors from locating a holding company in a jurisdiction are regulations aimed at counteracting tax evasion. These include, first of all, regulations concerning controlled foreign companies, which envisage attributing the income of a controlled foreign company located in a country offering preferential taxation to its shareholders and taxing this income in the shareholder's country of residence. This may apply both to shareholders who are legal persons and to shareholders who are individuals. Taxing the income of a controlled foreign company takes place even if the income is not paid in the form of dividends. Only a few countries have not 


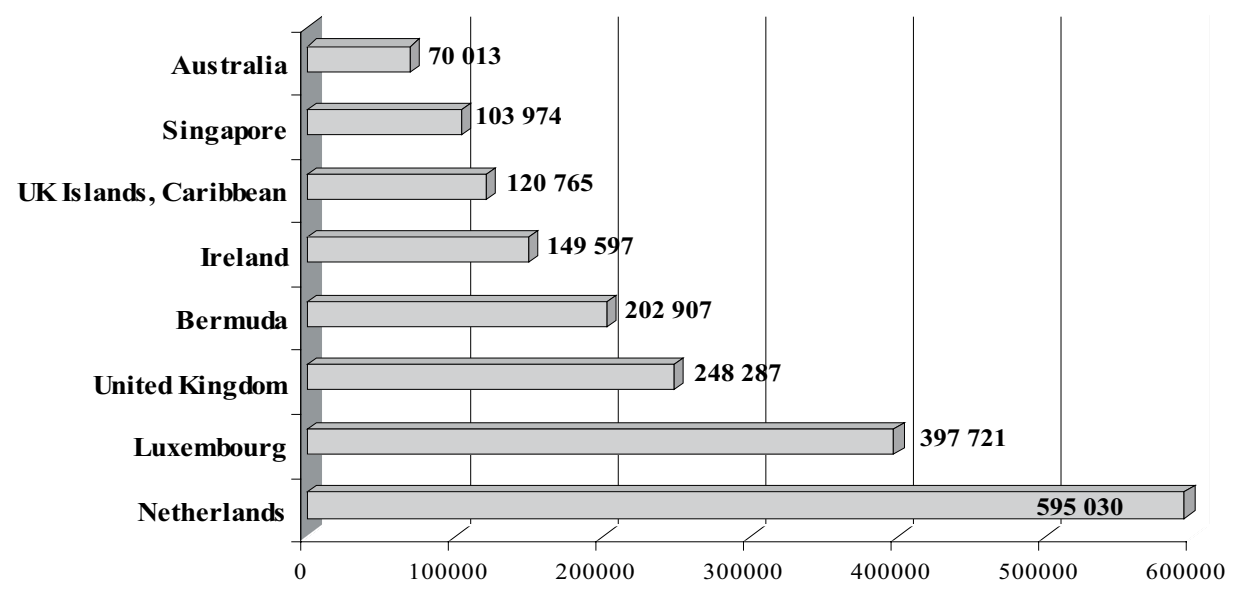

Fig. 1. US direct investment in holding companies in selected jurisdictions (historical-cost basis, millions of dollars, 2014)

Source: [U.S. Direct Investment Position Abroad on a Historical-Cost Basis, 2014].

introduced this sort of regulations into their legal systems [Guide to Controlled..., 2014, p. 71]. Therefore, what matters is not so much the existence of CFC institution itself but whether the definition of a controlled foreign company is broad or narrow, and whether the conditions of attributing the company's income to the income of shareholders are more or less restrictive.

Other factors influencing the choice of the location for a holding company in a jurisdiction may be: the tax on civil law transactions, the principles of deduction of losses from business activity, including in particular capital losses, the requirements for the creation of a tax group, regulations concerning thin capitalisation or the catalogue of expenses classified as tax deductible expenses.

Information on the popularity of different jurisdictions as locations for holding companies may be derived from the analysis of direct foreign investments in holding companies located in particular jurisdictions. Figure 1 presents data on American foreign direct investments published by the Bureau of Economic Analysis. The data for 2014 show that American investors locate their capital mostly in Dutch holding companies (fig. 1). The share of American foreign direct investments located in holding companies in the Netherlands amounts to about $25.2 \%$. Other locations with this respect include Luxemburg, Great Britain and Bermuda.

\section{Conclusion}

The attractiveness of a jurisdiction as a location of international business company depends not only on the scope and character of company's activities and its strategy, but also on a number of location-specific factors. For an international busi- 
ness company tax factors play a crucial role. However, the importance of tax determinants may be different depending on the company's type.

For the holding company, analysed in the article, the optimal location is a jurisdiction in which the law envisages exempting dividends obtained by the company and gains from the alienation of shares. Such jurisdictions are not only some classical tax havens but also certain European countries, such as the Netherlands, Luxemburg, Spain or Great Britain. The requirements which a holding company must meet to be entitled to these exemptions are varied.

Moreover, the most beneficial holding tax regimes offer an exemption from the taxation of dividends paid by a holding company and interests paid by it on debt instruments, as well as charges for licences and patents. Such exemptions are offered both by classical tax havens and some European countries. Among the preferred jurisdictions are also those which have concluded a number of double taxation agreements with other countries, have not introduced restrictive instruments counteracting tax evasion, do not impose tax on civil law transactions and have introduced a possibility of consolidation for tax purposes both in the case of the corporate income tax and the value added tax.

The analysis of data concerning American foreign direct investments in holding companies leads to a conclusion that the most attractive locations for holding companies are: the Netherlands, Luxemburg, Great Britain and Bermuda. The attractiveness of these jurisdictions is not only the effect of favourable tax regimes for holding companies but also a number of non-tax factors.

\section{Bibliography}

Broe L. de, International Tax Planning and Prevention of Abuse, International Bureau of Fiscal Documentation, Amsterdam 2008.

Brouthers L.E., Gao Y., McNicol J.P., Corruption and Market Attractiveness Influences on Different Types of FDI, “Strategic Management Journal” 2008, Vol. 29, No. 6, DOI: http://dx.doi.org/10.1002/smj.669.

Dunning J.H., Towards a New Paradigm of Development: Implications for the Determinants of International Business, "Transnational Corporations" 2006, Vol. 15, No. 1,

DOI: http://dx.doi.org/10.4337/9781849808064.00015.

Egger H., Winner H., How Corruption Influences Foreign Direct Investment: A Panel Data Study, "Economic Development and Cultural Change" 2006, Vol. 54, No. 2, DOI: http://dx.doi.org/10.1086/497010.

Eicke R., Tax Planning with Holding Companies - Repatriation of US Profits from Europe: Concepts, Strategies and Structures, Kluwer Law International, Alphen aan den Rijn 2009.

EY's Attractiveness Survey, Europe 2014, Back in the Game, London 2014.

Globerman S., Shapiro D., Governance Infrastructure and US Foreign Direct Investment, "Journal of International Business Studies” 2003, Vol. 34, No. 1, DOI: http://dx.doi.org/10.1057/palgrave.jibs.8400001.

Guide to Controlled Foreign Company Regimes, Deloitte, London 2014.

Hadnum L., The World's Best Tax Havens, Taxcafe UK Limited, Kirkcaldy 2009.

Hakkala K.N., Norbäck P.-J., Svaleryd H., Asymmetric Effects of Corruption on FDI: Evidence from Swedish Multinational Firms, "The Review of Economics and Statistics" 2008, Vol. 90, No. 4, DOI: http://dx.doi.org/10.1162/rest.90.4.627. 
International Master Tax Guide, CCH a Wolters Kluwer business, Sydney 2009.

Morisset J., Pirnia N., How Tax Policy and Incentives Affect Foreign Direct Investment: a Review, Policy Research Working Paper 2509, The World Bank and International Finance Corporation Foreign Investment Advisory Service, Washington DC 2000, DOI: http://dx.doi.org/10.1596/1813-9450-2509.

Russo R., Fundamentals of International Tax Planning, International Bureau of Fiscal Documentation, Amsterdam 2007.

Spengel Ch., Endres D., Finke K., Heckemeyer J., Effective Tax Levels Using the Devereux/Griffith Methodology, Zentrum für Europäische Wirtschaftsforschung, Mannheim 2014.

U.S. Direct Investment Position Abroad on a Historical-Cost Basis, 2014, www.bea.gov/international/ dilusdbal.htm [access: 10.09.2015].

Zvirgzde D., Schiller D., Diez J.R., Location Choices of Multinational Companies in Transition Economies: A Literature Review, European Commission, Brussels 2013.

\section{International Business Company in a Tax Haven: Selecting and Prioritizing Favourable Investment Locations}

The aim of this article is to indicate and characterise the determinants of the location decisions made by international business companies. The article presents the definitions and different types of international business companies. The final part of the article is devoted to the holding company and tax determinants of its location. On the basis of the data on American foreign direct investments in holding companies, the attractiveness of particular holding company locations is assessed.

\section{Przedsiębiorstwo międzynarodowe w raju podatkowym: wybór i priorytetyzacja atrakcyjnych inwestycyjnie lokalizacji}

Celem artykułu jest wskazanie i opisanie determinant decyzji lokalizacyjnych podejmowanych przez spółki międzynarodowe. W opracowaniu przedstawiono definicje i kategorie spółek międzynarodowych. Końcowa część została poświęcona spółkom holdingowym i determinantom podejmowanych przez te spółki decyzji lokalizacyjnych. Na przykładzie danych dotyczących amerykańskich bezpośrednich inwestycji zagranicznych w spółki holdingowe oceniono atrakcyjność inwestycyjną poszczególnych lokalizacji dla tej kategorii spółek międzynarodowych. 